\title{
Hubungan Peletakan Kamera (Angle) dalam Iklan Berbentuk Video
}

\author{
Bobby Halim ${ }^{1)}$ Yosef Yulius ${ }^{2)}$ \\ ${ }^{122)}$ Program Studi Desain Komunikasi Visual, Universitas Indo Global Mandiri \\ Jl Jend. Sudirman No. 629 KM. 4 Palembang Kode Pos 30129

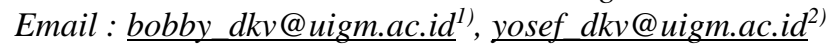

\begin{abstract}
In an advertisement sometimes there is a meaning that is presented not straightforward. Every TVC that uses real human talent cannot be separated from the camera's perspective. THE IMPORTANCE OF CAMERA VIEWS ON VIDEO MEDIA ADVERTISING examines the relationship of camera placement (angle) in influencing the message conveyed by a TVC and how cinematography is used as visual rhetoric. The study was conducted qualitatively with a semiotic film analysis approach. Data THE IMPORTANCE OF CAMERA VIEWS ON VIDEO MEDIA ADS is grouped into 4 structures, namely Visual Structure, Verbal Structure (Language, Character, Settings, Time), Narrative Structure and Audio Structure. Diachronic analysis using signifier (sign) and signified (sign) views. Some types of angles are Extreme Long Shot (ELS), Very Long Shot (VLS), Long Shot (LS), Medium Long Shot (MLS), Medium Shot (MS), Medium Close Up (MCU), Close Up (CU), Big Close Up (BCU), Low Angle Shot, Eye Level Shot. The selection of the selected images to be analyzed is carried out on the following basis: (1) Selecting an image according to the type of camera angle. (2) Sort images according to the type of camera angle. (3) Analyze each film and the impression built from each camera's perspective. (4) Comparing the impressions of the two analyzes. (5) Explain the reasons for the different impressions that arise, when the viewpoint of the camera is the same but the impression obtained is different. The camera angle is important in creating certain impressions, for example the impression of horror.
\end{abstract}

Keywords : advertisement, semiotics, film, cinematography

\begin{abstract}
Abstrak
Dalam sebuah iklan terkadang terdapat makna yang disajikan tidak lugas. Setiap TVC yang menggunakan talent manusia asli, tidak terlepas dari sudut pandang kamera. PENTINGNYA SUDUT PANDANG KAMERA PADA IKLAN MEDIA VIDEO menelaah hubungan peletakan kamera (angle) dalam mempengaruhi pesan yang disampaikan oleh sebuah TVC dan bagaimana sinematografi digunakan sebagai retorika visual. Kajian dilakukan secara kualitatif dengan pendekatan analisis semiotika film. Data PENTINGNYA SUDUT PANDANG KAMERA PADA IKLAN MEDIA VIDEO dikelompokan menjadi 4 struktur, yaitu Struktur Visual, Struktur Verbal ( Bahasa, Karakter, Setting, Waktu), Struktur Naratif dan Struktur Audio. Dianalisis secara diakronik dengan menggunakan pandangan signifier (penanda) dan signified (petanda).

Beberapa jenis angle yaitu Extreme Long Shot (ELS), Very Long Shot (VLS), Long Shot (LS), Medium Long Shot (MLS), Medium Shot (MS), Medium Close Up (MCU), Close Up (CU), Big Close Up (BCU), Low Angle Shot, Eye Level Shot.

pemilihan gambar-gambar yang dipilih untuk dianalisa, dilakukan dengan dasar berikut: (1) Memilih gambar yang sesuai jenis sudut pandang kamera. (2) Mengurutkan gambar berdasarkan jenis sudut pandang kamera. (3) Menganalisis masing-masing film dan kesan yang dibangun dari masing-masing sudut pandang kamera.

(4) Membandingkan kesan dari kedua analisis. (5) Menjelaskan sebab-sebab perbedaan kesan yang timbul, bila sudut pandang kamera sama tetapi kesan yang diperoleh berbeda.

Sudut pandang kamera penting dalam menciptakan kesan-kesan tertentu,misalnya kesan horor.
\end{abstract}

Kata kunci: iklan, semiotika, film, sinematografi 


\section{Pendahuluan}

Dewasa ini terdapat berbagai jenis film, meskipun pendekatannya berbeda-beda semua film dapat dikatakan mempunyai satu sasaran, yaitu menarik perhatian orang terhadap muatan masalah-masalah yang dikandung. Selain itu film tersebut dirancang untuk melayani keperluan publik terbatas maupun publik yang luas. Industri perfilman Indonesia sendiri masih terus berjuang menuju ke tingkat industri film yang mapan. Kendala utama yang dihadapi berkaitan dengan masalah permodalan, dukungan teknologi film (mulai dari pengadaan peralatan film sampai dengan penyediaan laboratorium modern tempat pemrosesan film), masalah kekurangan sumber daya manusia terampil, hingga ke soal-soal peredaran film yang bersaing keras dengan produksi film impor. Kendala lain yang sering muncul, soal kualitas dan iklim kreativitas dan atau kebebasan berkreasi bagi para pembuat film. Hal ini karena proses produksi film berhubungan erat dengan macam-macam faktor. Jurusan Desain Komunikasi Visual, Fakultas Seni dan Desain -Universitas Kristen Petra http://www.petra.ac.id/ puslit/journals/dir.php?Departm entID=DKV152.

Keinginan yang menggebu-gebu saja tidak cukup untuk membuat film yang baik dan sukses di pasaran (Sumarno, 1996:20-21). Pada akhirnya Industri film nasional terus berevolusi seiring dengan perkem- bangan ilmu pengetahuan dan teknologi serta sumber daya manusia negara kita.

Saat ini, film Indonesia secara nyata mulai menunjukkan geliat kembali. Sekalipun muncul kesan kalau film nasional yang laku saat ini hanya ada dua macam saja, film yang bertema remaja atau horor/ misteri. Dari sekitar 20 judul film yang diproduksi sepanjang 2003, sebagian besar bertemakan remaja atau anak muda, dan yang laku atau banyak ditonton adalah yang mengangkat kisah percintaan ala remaja masa kini, atau horor/misteri yang sedikit banyak terpengaruh dengan pola film horor barat (Andyana, 2004).

Film horor dibuat untuk menakut-nakuti penon- ton. Kebanyakan film horor bermodalkan sosok-sosok mengerikan untuk membuat penonton menjerit. Namun, penonton masa kini, utamanya anak-anak muda tidak mudah ditakut-takuti. Mereka bahkan bisa tertawa lebar jika melihat sosok pocong meloncat- loncat di layar lebar (Din \& Ida, 2003). Hal yang utama, dalam semua film horor, adalah cerita tentang kematian, fakta yang harus dihadapi setiap manusia. Fakta inilah yang diimajinasi dan diolah dalam film horor. Oleh karena itu film horor mengolah kisah mistis seputar masalah kematian, misalnya manusia berubah menjadi mahkluk aneh setelah melewati masa kematian, seperti zombie di Haiti, mumi di Mesir. Tiap-tiap film telah memiliki bentuknya sendiri untuk menggambarkan mahkluk-mahkluk yang membangkitkan perasaan gugup dan dingin yang mampu membuat penonton menggigil ketakutan. Teror-teror demikian mulai menjadi tren perfilman sejak tahun 1920-1930 an (Hutchinson, 1984:56).
Kegilaan hampir selalu menjadi kontroversi dalam aksi film horor. Film Alfred Hitchcock yang berjudul Psycho, yang dirilis tahun 1960, memantik film horor menjadi dua jenis, horor dan thriller. Film Indonesia yang berjenis horor, tampaknya berpotensi bersaing dengan film-film sejenis dari berbagai negara, utamanya Asia. Hal ini sebagai akibat dari kedekatan masyarakat Indonesia dengan hal-hal yang berbau mistik dan horor serta hal-hal supranatural lainnya. Kebanyakan masyarakat Indonesia masih percaya pada hal-hal gaib, hal ini dapat dilihat dari tingginya frekuensi pemunculan jenis-jenis tayangan tentang mengungkap keberadaan makhluk-makhluk halus oleh berbagai stasiun televisi. Selain itu, di Indonesia, masih banyak tempat yang dikeramatkan dan diangkerkan disamping maraknya praktik perdukunan yang dirilis oleh berbagai jenis media massa.

Tujuan penulisan artikel ini adalah menganalisa dua judul film horor yang terkenal yaitu film horor Indonesia yang sukses beredar di pasaran hingga ke luar negeri yaitu Jelangkung dibandingkan dengan Film Jepang yang sukses dan paling diingat masyarakat hingga saat ini yaitu The Ring 1. Dari berbagai jenis film yang diproduksi oleh negara kita, film horror dapat dikatakan mampu bersaing dengan film horor negara lain. Hal ini terbukti dengan jumlah penonton yang besar pada pemutaran film-film horor tersebut. Mempertahankan lebih sulit dibandingkan meningkatkan, oleh karena itu industri perfilman Indonesia tidak boleh hanya berhenti sampai di sini saja. Diharapkan dengan adanya analisa ini, insan- insan perfilman dapat membenahi diri untuk lebih baik lagi terutama dari sisi elemen audio visual yaitu sudut pandang kamera.

\section{A. Tujuan}

1. Mengetahui hubungan peletakan kamera (angle) dalam iklan berbentuk video.

\section{B. Manfaat}

1. Agar dapat menghasilkan penelitian-penelitian lanjutan mengenai hubungan peletakan kamera (angle) dalam iklan berbentuk video.

\section{Pembahasan}

Sebuah gambar memuat sebuah cerita, sebuah cerita memerlukan pemaparan. Gambar-gambar yang ada dalam film, merupakan gambar yang telah dipilih, dicari, dan diperhitungkan segala kemungkinan impak estetik dan ruang seni yang diciptakannya. Singkatnya shot adalah satu bagian dari rangkaian gambar yang begitu panjang, yang hanya direkam dengan satu take saja. Shot yang baik adalah kombinasi berbagai komposisi gambar ke dalam sambungan gambar yang utuh dan indah dalam satu kali pengambilan gambar.

Untuk itu penting untuk megetahui makna dari sebuah shot. Dalam film, gambar tidak bisa diambil seenaknya sendiri tanpa konsep yang jelas, karena dapat membingungkan penonton (Naratama, 2004:71- 72). Tiga faktor yang menentukan sudut pandang kamera 
yaitu: besar kecil subyek, sudut subyek, ketinggian kamera terhadap subyek. Besar kecil subyek hasil tangkapan kamera merupakan jenis-jenis shot yang mengambil sosok tubuh manusia sebagai referensi. Sudut subyek merupakan cara untuk mendapatkan efek dimensi kedalaman dalam pem- buatan film. Pemecahan soal termudah dengan meletakkan kamera sedemikian rupa terhadap obyek sehingga efek-efek kedalaman dapat direkam. Sedangkan ketinggian kamera terhadap obyek yaitu kemampuan kamera menangkap obyek dengan sudut pandang normal (eye level).

\section{Proxemics}

Proxemics berasal dari kata proximity yang mengacu pada jarak antara subject dan kamera, biasanya memiliki tiga posisi dasar yaitu long shot, medium shoot, close up dan extreme close up. Tetapi ada posisi alternatif yang tampak dan bisa dilaksanakan sebagai variasi dari tiga posisi dasar tadi. Dalam sebuah produksi televisi di studio, pengambil- an gambar bisa dideskripsikan pada operator kamera secara jelas, terutama perintah yang diberikan sutradara. Perintah ini tidaklah kaku, sutradara yang berbeda menggunakan bahasa yang berbeda pula (Mamer, 2003:19).

\section{Extreme Long Shot (ELS)}

Shot ini digunakan apabila gambar yang ingin diambil adalah gambar yang sangat-sangat jauh, panjang, luas dan berdimensi lebar. Biasanya diguna- kan untuk memperkenalkan seluruh lokasi adegan dan isi cerita. Extreme long shot digunakan untuk kompo- sisi gambar indah pada sebuah panorama (Naratama, 2004:73).

\section{Very Long Shot (VLS)}

Very long shot adalah pengambilan gambar yang panjang, jauh dan luas yang lebih kecil dari extreme long shot. Biasanya gambar-gambar yang diambil dengan VLS ini ditampilkan dalam film layar lebar. Utamanya pada gambar-gambar opening scene atau bridging scene, untuk menggambarkan adegan kolosal atau banyak objek misalnya adegan perang di pegunungan, adegan metropolitan dan sebagainya (Naratama, 2004:75).

\section{Long Shot (LS)}

Sebuah long shot (LS) sama dengan pengambilan gambar lainnya yang menampakkan keseluruhan tubuh manusia atau lebih. Pengambilan gambar yang hanya memasukkan manusia dari kepala hingga kaki, seringkali disebut sebagi "full body shot atau a full shot".

\section{Medium Long Shot (MLS)}

Pengambilan gambar medium long shot sering- kali dipakai untuk memperkaya keindahan gambar. : medium long shot menampilkan obyek dalam jarak yang cukup dekat dengan penonton, akan tetapi tetap menunjukkan bahasa tubuh subjek secara jelas (Naratama, 2004:75).

\section{Medium Shot (MS)}

Medium shot menampilkan gambar yang lebih memberikan detail pada manusia, karena gambaran yang diambil adalah gambaran yang menampilkan bagian tubuh dari pinggang keatas, hingga bisa menampakkan detil yang lebih jelas dari pada penam- pakan gambar yang menampilkan keseluruhan tubuh.

Akan tetapi biasanya shot ini menampilkan secara netral keseluruhan pokok subjeknya. Gambar ini mempresentasikan bagaimana biasanya manusia berinteraksi dengan orang lain dalam hidupnya, disesuaikan dengan kebudayaan negaranya. Medium Shot biasanya mengambil tampilan pada saat dua orang berbicara, sehingga bisa membuat penonton merasa berada sejajar dengan orang yang ditampilkan.

\section{Medium Close Up (MCU)}

Medium close up, dapat dikategorikan sebagai komposisi "Potret setengah badan", dengan background yang masih dapat dinikmati. Pengambilan gambar ini memperdalam gambar dengan lebih menunjukkan profil dari obyek yang direkam. Tampilan background menjadi hal kedua yang diperhatikan. Yang terpenting adalah profil, bahasa tubuh dan emosi tokoh utama dalam bingkai gambar ini dapat terlihat dengan jelas (Naratama, 2004:76).

\section{Close Up (CU)}

Pengambilan gambar close up biasanya merupa- kan pengambilan gambar utama. (lihat gambar 1). Penampilan gambar yang lebih dekat dari gambar 1, dimasukkan dalam kategori pengambilan gambar extreme close up. Ada juga pengambilan gambar yang diambil mulai dari pertengahan dada keatas, hal seperti ini disebut sebagai medium close up, yang seringkali digunakan.

Pengambilan gambar close up ini, biasanya menampilkan identifikasi psikologi sebuah karakter yang memerlukan perkuatan rincian detail berbagai aksi. Tampilan seperti ini ditayangkan, pada saat penonton diharuskan untuk menghadapi obyek utama, dan membuat hubungan tersendiri antara obyek dengan diri mereka secara psikologis. Identifikasi dalam bentuk pengambilan gambar close up ini adakalanya membuat pengambilan gambar menjadi berefek klaustropobik terhadap penonton. Pengambil- an gambar close up ini menekan ruang secara jelas, dan memberi batasan yang jelas antara penampilan aktor dan perasaan yang ditimbulkan oleh aktor dari bahasa tubuhnya. Penonton bisa memperoleh perasaan tertekan dan terancam karena kedekatannya. Pengambilan gambar seperti inilah yang membuat penampilan atau kualitas seorang aktor memainkan mimiknya menjadi hal yang penting. Pengambilan gambar secara close up berguna juga untuk menekankan detil. Hal ini juga sangat penting dalam hubungannya dengan fungsinya yang terutama untuk menciptakan ketegangan.

Berdasarkan penjelasan-penjelasan tentang pengambilan gambar diatas, bisa diketahui bahwa urutan pengambilan gambar long shot- medium shot- close up menampilkan sebuah gambaran secara netral, yang akan membuat penonton mulai merasa terikat dengan obyek utama. Urutan pengambilan gambar seperti ini 
menampilkan sebuah informasi yang acak dan tidak bisa dibedakan menjadi sebuah informasi yang lebih spesifik. Ketiga jenis pengambilan gambar ini pulalah yang menjadi dasar atas terjadinya sebuah film (Mamer, 2003:20-21).

\section{Big Close Up (BCU)}

Pengambilan gambar ini lebih tajam dari pengambilan gambar close up terutama untuk film horor yang menggunakan efek cahaya memantul pada sudut mata obyek. Kedalaman pandangan mata, kebencian raut wajah, kehinaan emosi hingga keharuan adalah ungkapan-ungkapan yang terwujud dalam komposisi gambar ini. Sementara untuk produksi talk show dan kuis, shot ini digunakan terutama untuk menggambarkan reaksi penonton yang larut dalam pembicaraan talk show di studio. Tanpa kata-kata, tanpa bahasa tubuh, tanpa intonasi big close up sudah mewujudkan semuanya. Pada pengambilan gambar ini, depth of field akan sulit didapatkan, namun bagi sutradara televisi, kekurangan ini dianggap sebagai kekuatan, karena gambar yang tidak fokus akan memiliki nilai artistik tersendiri (Naratama, 2004:77).

Extreme close up banyak digunakan pada pembuatan video klip, pada pengambilan gambar ini kekuatan dan ketajaman hanya fokus pada satu obyek misalnya dapat dilakukan extreme close up pada hidung, mata, atau alis saja. Pada pengambilan gambar ini, depth of field akan sangat sulit didapatkan karena kedekatan jarak objek dengan kamera. Seringkali apabila kamera diarahkan pada detail bagian mulut atau hidung, gambar akan menjadi tidak fokus (Naratama, 2004:78).

\section{Low Angle Shot}

Pemilihan ini dilakukan sebagai dasar untuk mempermudah analisa dan memperoleh perbandingan dan kesimpulan. Pada bagian pertama merupakan analisa komparasi kedua jenis film ini, digunakan tabel yang berisi kolom-kolom:

1. Teori: menunjukkan jenis sudut pandang kamera yang akan dianalisa. Pemilihan teori sudut pan- dang kamera ini berdasarkan analisa penulis akan hal-hal yang menimbulkan kesan horor.

2. Analisa: hasil analisa penulis terhadap sudut pandang kamera dan kesan yang timbul dari tujuan pengambilan gambar tersebut. Analisa ini seminimal mungkin dikaitkan dengan alur cerita film, sehingga analisa ini lebih fokus pada sudut pandang kamera.

3. Kesan: Kesan yang disimpulkan, berdasar atas analisa penulis. Kesan ini dirangkum berdasarkan teori tentang 6 kesan yang membangun cerita horor.

4. Kesan yang membangun film horor ini yaitu: netral, dingin, gugup, tegang, takut dan shock. Netral: berdiri sama tengah (tidak membantu/ tidak mengikut salah satu pihak)

Dingin: Tidak hangat, tidak panas, sejuk. Kedinginan : 1. kena dingin, menderita dingin, kese- jukan; 2. Sangat tertarik hatinya, sagat suaka (akan); 3. Berlagak (kaya, tahu, dsb) Gugup-menggugupkan: menyebabkan gugup (bingung). Dalam film horor, berarti menyebabkan timbulnya perasaan yang mulai memacu jantung. Reaksi yang timbul karena suatu hal yang membingungkan atau membuat penasaran.

Tegang: kencang (regang, seperti tali yang ditarik/ direntangkan). Pada kesan yang ditimbulkan pada saat melihat film horor, berarti merupakan perasaan yang hampir menuju batas.

Takut: (akan, kepada): merasa tak berani (ngeri, gentar) melihat dan sebagainya sesuatu yang pada perasaannya akan mendatangkan bencana bagi dirinya (Kamus Besar Bahasa Indonesia).

Shock: goncangan, kekejutan, teramat sangat mengejutkan. (Echols \& Shadily, 1984).

Analisis dibagi dua bagian, pada bagian kedua, analisis didapat berdasarkan pendapat penonton.yaitu responden sebanyak 20 orang yang mengerti tentang audio visual. Penonton tersebut dikondisikan untuk menonton kedua film dan mengisi kuesioner yang disediakan. Tabel analisa ini memiliki kolom-kolom sebagai berikut :

1. Kolom gambar berfungsi untuk sudut pandang kamera yang dimaksud.

2. Kolom jenis sudut pandang kamera.

Posisi kamera berada di bawah subjek bila melakukan pengambilan gambar dengan low angle shot. Kamera dalam posisi menengadah ke atas pada saat mengambil gambar. Pengambilan gambar dengan cara seperti ini cenderung membuat karakter atau lingkungan tampak mengancam, berkuasa atau mengintimidasi.

Memberikan penampilan yang menyimpang, mempertontonkan sebuah dunia diluar keseimbangan. Sudut pandang kamera ini dapat menciptakan perasaan antara tak memiliki arah dan tak terarahkan.

\section{Eye Level Shot}

Pengambilan gambar-gambar penting dalam filmfilm teater dan film seri kebanyakan dilakukan dengan eye level shot. Pengambilan gambar pada perfilman teater dan serial, jarang menggunakan cara high angle dan low angle shots, karena pengambilan gambar dengan cara ini bisa disalahartikan secara dramatis oleh penonton. Posisi kamera yang terlalu sejajar akan menyebabkan timbulnya konfrontasi secara langsung dengan penonton.

\section{A. Analisis}

Analisis kedua film The Ring dan Jelangkung dilakukan dengan memperhatikan adegan-adegan yang berlangsung. Adegan tertentu yang membangun cerita dan menimbulkan kesan horor akan diperhati- kan, dan dari adegan tersebut, dipilih gambar-gambar yang mampu mewakili keseluruhan adegan. Pengam- bilan gambar dengan cara printscreen per frame.

Pada setiap cerita secara garis besar, terdapat bagian pembuka, perumusan masalah, konflik, klimaks, penyelesaian masalah, penutup. Dalam film horor hal demikian juga berlaku. Akan tetapi syarat- syarat terjadinya sebuah cerita dalam pembuatan film tidak berlaku secara mutlak. Oleh karena itu pemilihan 
gambar-gambar yang dipilih untuk dianalisa, dilakukan dengan dasar berikut:

1. Memilih gambar yang sesuai jenis sudut pandang kamera.

2. Mengurutkan gambar berdasarkan jenis sudut pandang kamera.

3. Menganalisis masing-masing film dan kesan yang dibangun dari masing-masing sudut pandang kamera.

4. Membandingkan kesan dari kedua analisis.

5. Menjelaskan sebab-sebab perbedaan kesan yang timbul, bila sudut pandang kamera sama tetapi kesan yang diperoleh berbeda.

Pemilihan ini dilakukan sebagai dasar untuk mempermudah analisa dan memperoleh perbandingan dan kesimpulan. Pada bagian pertama merupakan analisa komparasi kedua jenis film ini, digunakan tabel yang berisi kolom-kolom:

1. Teori: menunjukkan jenis sudut pandang kamera yang akan dianalisa. Pemilihan teori sudut pan- dang kamera ini berdasarkan analisa penulis akan hal-hal yang menimbulkan kesan horor.

2. Analisa: hasil analisa penulis terhadap sudut pandang kamera dan kesan yang timbul dari tujuan pengambilan gambar tersebut. Analisa ini seminimal mungkin dikaitkan dengan alur cerita film, sehingga analisa ini lebih fokus pada sudut pandang kamera.

3. Kesan: Kesan yang disimpulkan, berdasar atas analisa penulis. Kesan ini dirangkum berdasarkan teori tentang 6 kesan yang membangun cerita horor.

4. Kesan yang membangun film horor ini yaitu: netral, dingin, gugup, tegang, takut dan shock. Netral: berdiri sama tengah (tidak membantu/ tidak mengikut salah satu pihak)

Dingin : Tidak hangat, tidak panas, sejuk. Kedinginan: 1. kena dingin, menderita dingin, kese- jukan; 2. Sangat tertarik hatinya, sagat suaka (akan); 3. Berlagak (kaya, tahu, dsb) Gugup-menggugupkan: menyebabkan gugup (bingung). Dalam film horor, berarti menyebabkan timbulnya perasaan yang mulai memacu jantung. Reaksi yang timbul karena suatu hal yang membingungkan atau membuat penasaran.

Tegang : kencang (regang, seperti tali yang ditarik/ direntangkan). Pada kesan yang ditimbulkan pada saat melihat film horor, berarti merupakan perasaan yang hampir menuju batas.

Takut : (akan, kepada): merasa tak berani (ngeri, gentar) melihat dan sebagainya sesuatu yang pada perasaannya akan mendatangkan bencana bagi dirinya (Kamus Besar Bahasa Indonesia).

Shock : goncangan, kekejutan, teramat sangat mengejutkan. (Echols \& Shadily, 1984).

Analisis dibagi dua bagian, pada bagian kedua, analisis didapat berdasarkan pendapat penonton.yaitu responden sebanyak 20 orang yang mengerti tentang audio visual. Penonton tersebut dikondisikan untuk menonton kedua film dan mengisi kuesioner yang disediakan. Tabel analisa ini memiliki kolom-kolom sebagai berikut:
1. Kolom gambar berfungsi untuk sudut pandang kamera yang dimaksud.

2. Kolom jenissudutpandang kamera.

3. Kolom analisa yang berfungsi untuk menyam- paikan hasil akhir analisa penonton terhadap sudut pandang kamera yang dapat menciptakan kesan menakutkan (horor).

\section{B. Analisis Sudut Pandang Kamera}

Sudut pandang kamera tipe extreme long shot dalam film Jelangkung dan The Ring 1 mempunyai tujuan yang sama yaitu menampilkan suatu lokasi yang luas. Dalam film The Ring 1 shot ini dimanfaat- kan untuk menunjukkan lokasi yang menakutkan secara keseluruhan. Kesan yang ditampilan oleh tipe shot ini netral.

Sudut pandang kamera tipe medium long shot dalam film Jelangkung dan The Ring 1 mempunyai tujuan yang berbeda. Dalam film Jelangkung tipe shot ini digunakan untuk menampilkan gambar artistik untuk menarik perhatian penonton, sehingga kesan yang ditampilkan netral. Sedangkan dalam film The Ring 1 tujuan pengambilan sudut pandang kamera adalah menampilkan bahasa tubuh obyek yang takut dan menakutkan, sehingga dapat membuat gugup. Kesan yang ditampilkan oleh tipe shot yang sama ternyata berbeda, hal ini tergantung cerita yang dibangun.

Sudut pandang kamera tipe very long shot dalam film Jelangkung dan The Ring 1 mempunyai tujuan yang sama yaitu menunjukkan keberadaan subyek dengan lingkungan sekitar yang menakutkan. Ter- nyata kesan yang didapat oleh penulis berbeda, dalam film Jelangkung sudut pandang yang ditampilkan dapat membuat shock, sedangkan dalam film The Ring 1 membuat tegang. Kesan yang timbul berbeda tergantung cerita yang dibangun dan faktor penca- hayaan.

Sudut pandang kamera tipe long shot dalam film Jelangkung dan The Ring 1 mempunyai tujuan yang berbeda. Pada film Jelangkung tipe shot ini seolah ingin menampilkan gambar yang artistik, sehingga kesan yang ditampilkan hanya netral. Di film The Ring 1 tipe shot ini menampilkan posisi obyek dengan kondisinya yang menakutkan, sehingga berhasil membangun kesan yang menakutkan. Kesan yang ditimbulkan kedua film ini sangat berbeda, hal ini diakibatkan faktor pencahayaan dan fokus gambar.

Sudut pandang kamera tipe medium shot dalam film Jelangkung dan The Ring 1 mempunyai tujuan yang hampir sama. Pada film Jelangkung tipe shot ini menggambarkan suatu keadaan yang menakutkan. Sedangkan pada film The Ring 1 sudut pandang kamera ini menjelaskan posisi dua obyek yang berhadapan, suatu posisi yang menakutkan. Keduanya berhasil menciptakan ketegangan.

Sudut pandang kamera tipe medium close up dalam film Jelangkung dan The Ring 1 mempunyai tujuan yang sama, yaitu memperlihatkan mimik ketakutan dan gerak tubuh obyek terhadap ruang disekitarnya. Kedua sudut kamera ini dapat mencipta- kan ketegangan. 
Sudut pandang kamera tipe close up dalam film Jelangkung memperlihatkan mimik ketakutan. Pada film The Ring 1 mimik ketakutan ini diperjelas lagi dengan mata terbelalak dan mulut terbuka, sehingga kesan yang dihasilkan tidak hanya membuat tegang, tetapi sudah dapat menimbulkan perasaan takut. Kesan yang ditimbulkan sedikit berbeda diakibatkan oleh alur cerita dan faktor pencahayaan.

Sudut pandang kamera tipe big close up dalam film Jelangkung dan film The Ring 1 mempunyai tujuan yang sama yaitu menyorot lebih dekat wajah tokoh yang terlihat ketakutan, tetapi kesan yang dihasilkan oleh sudut pandang kamera close up di Film Jelangkung dan film The Ring 1 berbeda. Pada film Jelangkung, sudut pandang kamera big close up dapat menimbulkan rasa takut, tetapi pada film The Ring 1 penulis dapat merasakan ketegangan. Perbedaan kesan ini diakibatkan oleh perbedaan alur cerita dan faktor pencahayaan.

Sudut pandang kamera tipe extreme close up dalam film Jelangkung menampilkan detail bagian dari wajah tokoh yang ketakutan, hal ini dapat menimbulkan rasa takut. Sedangkan pada The Ring 1 tujuan penggunaan sudut pandang kamera extreme close up adalah menampilkan detail bagian dari wajah tokoh yang menakutkan. Sudut pandang kamera ini dapat menghasilkan efek takut dengan level paling tinggi yaitu shock. Tujuan penggunaan sudut pandang kamera yang ditampilkan berbeda sehingga meng- hasilkan kesan yang juga berbeda.

Sudut pandang kamera tipe low angle dalam film Jelangkung digunakan untuk menjelaskan aktivitas yang sedang berlangsung. Pada film The Ring 1 aktivitas diperlihatkan lebih detail lagi dengan mem- perlihatkan mimik wajah. Kesan yang dihasilkan oleh kedua sudut pandang kamera di kedua film tersebut adalah netral.

Sudut pandang kamera tipe eye level shot dalam film Jelangkung digunakan agar penonton dapat melihat jelas obyek yang menakutkan, sehingga memperoleh kesan menakutkan. Tujuan sudut pandang kamera tipe eye level shot pada film The Ring 1 sama yaitu agar penonton dapat melihat bagian wajah yang menakutkan, sehingga dapat membuat shock. Kesan yang timbul dari kedua film tersebut dengan sudut pandang yang sama ternyata berbeda, hal ini dapat disebabkan karena faktor pencahayaan dan teknik editing yang tidak sama.

Dalam film horor, angle-angle yang digunakan adalah: extreme long shot, medium long shot, very long shot, long shot, medium long shot, medium close up, medium shot, close up, extreme close up, low angle shot dan eye level shot. Angle-angle yang paling memberikan kesan horor adalah close up, big close up, extreme close up dan eye level shot. Sudut pandang kamera dapat dikatakan memberikan kesan horor apabila pengamat mamperoleh kesan tegang, takut dan shock.

\section{Kesimpulan}

Sudut pandang kamera penting dalam mencipta- kan kesan-kesan tertentu,misalnya kesan horor. Penggunaan angle-angle yang paling mendukung terciptanya kesan horor dalam film, adalah angle close up, big close up, extreme close up, dan eye level shot. Pengambilanpengambilan gambar dengan sudut pandang kamera ini mampu memper- lihatkan detil mimik wajah obyek secara jelas. Dalam film horor, mimik-mimik seperti ketakutan, kengerian dan kekejaman sangat penting peranannya dalam membangun cerita dan membuat penonton merasa dingin, gugup, tegang, takut dan shock. Oleh karena itu sudut pandang kamera dalam film sebaiknya memikirkan fungsinya sebagai pembangun cerita. Sebuah film dibangun bukan dengan sekedar menem- patkan gambar-gambar indah sebanyak mungkin dalam film, atau gambar-gambar untuk menakut- nakuti saja. Sudut pandang yang sama, belum tentu dapat menghasilkan kesan yang sama. Melalui analisis diatas ternyata selain sudut pandang kamera terdapat faktor lain seperti: alur cerita, teknik editing, penca- hayaan dan efek pencahayaan serta kejelasan gambar, yang juga mempengaruhi kesan yang diperoleh, belum lagi ditambah dengan efek audio yang digunakan.

Film Jelangkung menonjolkan kesan video klip karena kedinamisan penampilannya dan efek cahaya yang digunakan. Film ini kurang berkesan horor, hal ini mungkin juga disebabkan karena sutradara film Jelangkung (Rizal Mantovani) adalah spesialis pembuat video klip. Informasi-informasi yang diberi- kan kepada penonton kurang dapat membangun cerita dan klimaks sebagai film horor. Banyak tampilan visual film Jelangkung yang memperlihatkan adegan- adegan yang sama dengan sosok-sosok horor The Ring 1, akan tetapi dalam film Jelangkung penam- pilan-penampilan ini kurang didukung oleh penyajian yang baik, selain itu durasi pergantian frame tiap adegan berlangsung singkat; hal ini kurang men- dukung kesan horor yang dapat diperoleh penonton.

\section{Saran Akademis}

1. Diharapkan penelitian sejenis dapat menggunakan metode-metode lain dari semiotika. Penelitian ini memakai metode dari Ferdinand de Saussure yaitu Signifier dan Signified. Terdapat metode lain yang kiranya dapat digunakan dalam meneliti sebuah iklan televisi dari tokoh - tokoh semiotika lain, seperti Charles Sanders Peirce, Roman Jakobson, Louis Hjelmslev, Roland Barthes hingga Jacques Derrida.

1. Penelitian ini ingin mendorong penelitian-penelitian lain untuk mengkaji iklan-iklan televisi yang menerapkan teknik sinematografi dalam proses kreatifnya, dalam mencari makna-makna eksplisit maupun implisit yang terkandung.

\section{Saran Praktis}

1. Kiranya lebih banyak praktisi yang mau turut serta memberikan pengetahuan mengenai seluk beluk sinematografi dengan cara aktif mengajar baik secara formal maupun non-formal, seperti seminar maupun workshop. 
2. Kiranya juga diharapkan lebih banyak terbit buku pelajaran Sinematografi yang bersifat lokal namun berbobot internasional.

3. Diharapkan iklan - iklan komersil di Indonesia memberikan nilai - nilai positif.

\section{Daftar Pustaka}

Manurung, Parmonangan. 2009. Desain Pencahayaan Arsitektural_Konsep Pencahayaan Artificial pada Ruang Eksterior, Yogyakarta: Penerbit Andi

Melville C. Branch. 1995. Comprehensive City Planning:Introduction \& Explanation. Amerika: The Planner Press of the American Planning Association

Joseph De Chiara \& LeeE Koppelman. 1975. Site Planning Standart. NewYork : Regional Plan Association, Inc.

Prof. Ir. Eko Budihardjo, MSc. 1991. Arsitektur Dan Kota di Indonesia. Bandung : Penerbit Alumni.

Markus, Zahud. 2008. Model Baru Perancangan Kota Yang Berkontekstual. Yogyakarta: Penerbit Kanisius

Kurniawan. 2001. Semiologi Roland Barthes. Magelang: Indonesiatera. 